\title{
The Influence of Organizational Citizenship Behavior (OCB) And Organizational Culture on The Performance of Education Employees as Mediated by Job Satisfaction (Survey at the Private University of Sleman Regency in Yogyakarta)
}

\author{
Titi Laras ${ }^{1}$, Bambang Jatmiko², \\ Fransiskus Joki Hartono Tri Nugroho ${ }^{3}$ \\ 1 Janabadra University \\ ${ }^{2}$ Universitas Muhammadiyah Yogyakarta \\ 3Universitas Atma Jaya Yogyakarta \\ joki.hartono@uaiy.ac.id
}

\begin{abstract}
UU No. 12 of 2012 concerning Higher Education, discusses universities that are formed and managed on a non-profit basis, called private universities. The difference between public and private, only the founders and managers, for the form of both are similar. Private Universities need competent human resources to manage them. This type of research is quantitative research. The population of this study was employees at a private university in Sleman Regency, Yogyakarta. The sampling technique that will be used is the proportional stratified random sampling method with a total sample of 130 people. The analysis used is Structural Equation Modeling (SEM) analysis. Based on the results of data analysis, the following conclusions are obtained: (1) Organizational Citizenship Behavior (OCB) has a positive effect on Employee Job Satisfaction; (2) Organizational Culture has a positive effect on Employee Job Satisfaction; (3) Organizational Citizenship Behavior (OCB) has a positive effect on the Performance of Educational Employees of Private Universities in Sleman Regency, Yogyakarta; 4) Organizational Culture has a positive effect on Employee Performance; (5) Job satisfaction has a positive effect on employee performance; (6) Job satisfaction is not able to mediate the effect of the variable Organizational Citizenship Behavior $(\mathrm{OCB})$ on the Performance of Educational Employees at Private Universities in Sleman Regency, Yogyakarta; and (7) job satisfaction is not able to mediate the influence of organizational culture on employee performance.
\end{abstract}

Keywords: Organizational Citizenship Behavior (OCB), Organizational Culture, Job Satisfaction, Employee Performance 
JEL $\quad:$ M12

DOI $\quad: 10.24002 /$ kinerja.v25i2.4814

Received : 08/09/2021 Reviewed: 09/06/2021 Final Version: 09/08/2021

\section{INTRODUCTION}

UU No. 12 of 2012, concerning Higher Education, discusses private universities, which are formed and managed for a non-profit purpose. Only the founders and managers distinguish between public and private, as the forms of both are similar. Private universities require competent human resources to manage; for example, the Sleman Regency in Yogyakarta employs 771 people. Table 1.1 summarizes the information.

Table 1. Data on Educational Employees at Four Private Universities in Sleman

\begin{tabular}{clc}
\hline No & \multicolumn{1}{c}{ Details } & Total \\
\hline 1 & Yogyakarta Atma Jaya University & 255 \\
2 & Yogyakarta Sanata Dharma University & 257 \\
3 & Yogyakarta AMIKOM University & 90 \\
4 & Yogyakarta RESPATI University & 169 \\
& Total & 771 \\
\hline
\end{tabular}

Given a large number of educational employees at Sleman Regency universities, university administrators must be able to optimize these employees' performance. These steps are being taken to increase productivity. Employee productivity can be determined by the level of performance demonstrated. This can also arise when managers can optimize employees' roles. Superiors must master the science of organizational behavior to provide directions and guidance to employees so that they act by their goals.

Individuals, groups, organizations, and environmental factors all contribute to different levels of organizational behavior (Umam, 2012:34). According to Robbins and Judge (2015:25), each level has its process, such as character, action, and performance at the individual level. The findings of the study will be discussed at the individual level, specifically Organizational Citizenship Behavior (OCB). The organ in Luthans (2011:149) defines OCB as a non-formalized action that adds value and improves the organization's effectiveness. Altruism, Civic Virtue, Sportsmanship, Conscientiousness, and Courtesy are the five dimensions of OCB attitudes (Luthans, 2011: 149).

OCB is important not only for improving employee performance but also for achieving employee job satisfaction. Job satisfaction, according to Robbins and Judge (2007), can be interpreted as individual behavior related to interactions with 
records, obeying rules, and organizational rules for standardization of work. According to Robbins and Judge (2017), when employees are satisfied with their performance, they will speak positively about the organization. Job satisfaction can be interpreted as an evaluation of individual work outcomes (Weiss and Merlo, 2015). According to Dewi and Suwadana (2016), job satisfaction has a positive impact on OCB. According to other research, Lestari and Ghaby (2018) agree that OCB has a positive impact on satisfaction and performance. Job satisfaction is directly proportional to performance, or it can be said that job satisfaction mediates OCB with performance.

The perspectives of organizational members are interpreted by organizational culture. In Liliweri (2014:276), Reynecke defines culture as a way of life, insights, moral values, attitudes, life events, and religion held by one group and passed down to the next generation. A group's culture imprints the rules. Meanwhile, organizational culture allows for changes in rules as a result of regulations and adjustments to inherited generations. According to Mayowan et al. (2016: 60), organizational attitudes can reflect the relationship between organizational culture and the performance of its members. When employees adopt this attitude, they experience satisfaction and appreciation. Organizational culture functions as a road map for its members to follow. Robbins (2006: 60) emphasizes the link between organizational culture and employee performance, stating that when there is an organizational culture in place, employees are more committed. Even within the company, the recruitment process and employee development are influenced by culture. Isnada (2016) agrees, and his research shows that organizational culture has a positive impact on employee performance.

An optimal organizational culture can also lead to job satisfaction. Robbins (2006) describes this in terms of several factors, the first of which are tasks that demonstrate their expertise and appreciation for the results, and the second of which is the work environment, which includes comfortable conditions by the applicable rules. In agreement with this, Khan et al (2011), Sabri et al. (2011), and Emami et al. (2012) found a positive correlation between organizational culture and job satisfaction in their research.

Based on the description above, it is essential for every organization, particularly private universities in the Sleman Regency area, to improve employee performance and job satisfaction. However, preliminary research indicates that not all educational employees at private universities in the Sleman Regency area perform optimally. This can be seen in the less optimal use of employees during working hours, as many employees are engrossed in playing gadgets and chatting or drinking coffee during working hours. Some employees expressed dissatisfaction with their jobs for a variety of reasons, including low pay, unclear career paths, and a lack of overtime pay. This causes them to focus solely on their primary job, making it difficult to instill OCB in these employees. Furthermore, the current organizational culture is not conducive because the work environment is generally relaxed, and employees 
understand that no matter how good their performance is, it will have little impact on their career paths and salaries.

Based on the description above, this study aims to find out and obtain empirical evidence to obtain an answer on the influence of Organizational Citizenship Behavior (OCB) on Job Satisfaction, Organizational Culture on Job Satisfaction, Organizational Citizenship Behavior (OCB) on Performance, Organizational Culture on Performance, Job Satisfaction on Performance, Organizational Citizenship Behavior (OCB) on Performance mediated by Job Satisfaction, and Organizational Culture on Educational Employee Performance mediated by Job Satisfaction at Private Universities in Sleman Regency, Yogyakarta.

\section{LITERATURE REVIEW}

Organizational leaders are generally aware of differences in performance between one employee and other employees under their supervision. Even though employees work in the same location, their productivity is not the same. In general, this difference in performance is caused by two factors (As'ad 2006:49), namely, individual factors and work situations. Individual factors include job satisfaction and OCB, while work situation factors can take the form of organizational culture. Organizations with high OCB will have employees who perform better than other organizations (Robbins and Judge, 2007:40).

OCB is not only important for improving employee performance, but it is also important for increasing employee job satisfaction. Job satisfaction has the potential to mediate the relationship between OCB and employee performance (Lestari and Ghaby, 2018: 116). Organizational culture can also affect employee performance. This is understandable given that employees with a strong organizational culture are more committed to their organization. This dedication is reflected in excellent performance (Robbins, 2000:60). Employee performance can benefit from a positive work culture (Isnada, 2016:62). Because a conditional organizational culture provides personal comfort and ease of doing work, a good organizational culture can also foster employee job satisfaction (Robbins, 2000:37). The following is a more detailed description of the relationship between OCB, organizational culture, job satisfaction, and employee performance:

\subsection{The Impact of OCB on Job Satisfaction}

OCB is an employee's behavior that contributes more than the demands of his job, whereas job satisfaction is a positive emotional state that results from an evaluation of one's job or work experience (Kaswan, 2012). OCB is critical to the company's success and sustainability, so it must be increased and improved. Because job satisfaction is an employee's perception of their work, everyone's job satisfaction will differ. Many factors influence job satisfaction, including salary compatibility, work facilities, coworker relationships, employee advancement opportunities, leadership supervision, and the work itself (Belo, Riana, \& Priartini 
(2014); Nurbahar (2015); Pratama and Sriathi (2015); Weiss and Merlo (2015)). Several previous studies have found that OCB is a significant predictor of job satisfaction (Cohen and Vigoda (2000); Todd 2003). The following ideas are proposed in this study:

H1: Organizational Citizenship Behavior (OCB) has a positive effect on Job Satisfaction of Private University Education Employees in Sleman Regency, Yogyakarta.

\subsection{The Impact of Organizational Culture on Job Satisfaction}

According to Robbins (2006:36), several important factors contribute to increased job satisfaction. The first is jobs that allow employees to use their skills and provide feedback on how well they work. The second is how employees work conditions, both in terms of personal comfort and satisfaction. To clarify, Robbins (2006:748) describes this as in the image below. These things are closely related to the rules and standards that have been determined by the company, while the rules and standards are formed from the organizational culture within the company itself.

The process flow depicted in the figure below explains how culture can affect job satisfaction. The characteristics of organizational culture will determine whether the organization has a strong or weak culture, and the strength of the organization's culture will ultimately determine employee satisfaction and performance. According to research by Khan et al. (2011), Sabri et al (2011), and Emami et al. (2012), there is a significant positive correlation between organizational culture and job satisfaction.

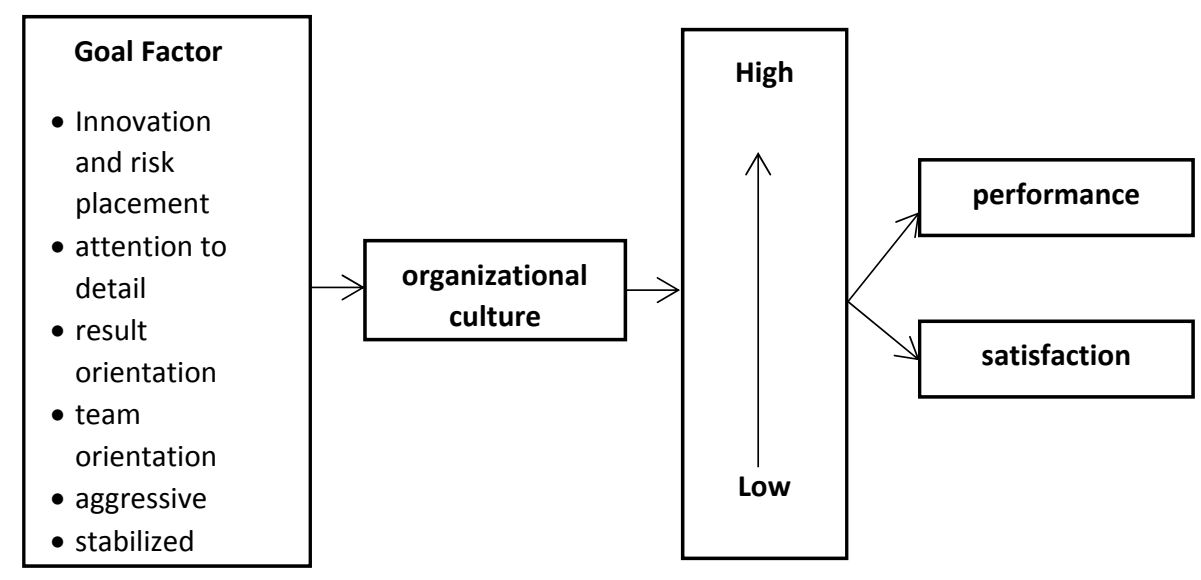

Figure 1. The Effect of Organizational Culture on Performance and Satisfaction (Robbins, 2006) 
As a result, the following hypotheses are put forward in this study:

H2: Organizational Culture has a positive effect on Job Satisfaction of Private University Education Employees in Sleman Regency, Yogyakarta.

\subsection{The Impact of OCB on Employee Performance}

The success of an industry is determined not only by the behavior of employees who are defined by their job descriptions (in-role behavior) but also by the behavior of employees who are not defined by their job descriptions (extra-role behavior). OCB is an individual's behavior that is free and explicitly rewarded by the formal reward system, and it promotes the effectiveness of organizational functions in general (Organ \& Lingl, 1995; Organ, 2015). Hui et al. (2000) discovered that organizations that encourage employees to go above and beyond the scope of their job have a distinct advantage over competitors. As a result, many employers prefer that their employees have OCB.

According to Purba and Seniati (2004), one advantage of OCB is that it can boost work productivity. This statement is supported by the findings of Podsakoff et al. (2000), who discovered that OCB could have an impact on organizational performance. Several studies on the impact of OCB on employee performance have found a significant positive relationship. Chien (2003); Alhamda \& Sanusi (2006); Bachrach, Powell, Bendoly, \& Richey (2006), but the findings of Buentelo, Jung, \& Sun (2008) show that the effect is not statistically significant. Despite inconsistencies in the research findings, it appears that there is a significant positive relationship between OCB and employee performance. As a result, the following hypotheses are put forward in this study:

H3: Organizational Citizenship Behavior (OCB) improves the performance of private university education employees in Sleman Regency, Yogyakarta.

\subsection{The Impact of Organizational Culture on Employee Performance}

Organizational culture binds employees who work in it to behave by the existing organizational culture. If this understanding is drawn into the organization, a set of norms has become a culture in the organization, so that employees must behave and behave by the existing culture without feeling forced (Yulian, 2015: 47).

The presence of culture in an organization acts as a glue and guideline for all company policies and operational demands for other aspects of the organization. Corporate culture can contribute to organizational performance if cultural values are used as guidelines when developing organizational rules. This means that if the organizational culture is positive, the organizational performance will be positive as well (Yulian, 2015: 47). 
Organizational culture is a set of values that are shared by all members of the organization and that are continuously studied, applied, and developed. It serves as an adhesive system and can be used as a reference for behavior within the company to achieve the company's goals, which can have an impact on organizational performance directly or indirectly. According to Indah Isnada's (2016) research, organizational culture has a positive impact on employee performance. Employees who are happy with their jobs and find them enjoyable tend to perform well. As a result, organizational culture has a positive and significant impact on employee performance. As a result, the following hypotheses are put forward in this study:

H4: Organizational Culture Improves the Performance of Private University Education Employees in Sleman Regency, Yogyakarta

\subsection{The Impact of Job Satisfaction on Performance}

Job satisfaction, as an attitude, will influence a person's behavior (action). According to Robbins (2003) and Sayekti et al. (2011), there is a strong correlation between job satisfaction and performance. Furthermore, when viewed at the organizational level, there is support for the relationship between job satisfaction and performance, as it is known that organizations with more satisfied employees tend to be more effective when compared to organizations with less satisfied employees. In terms of job satisfaction and performance, Luthans (2011) claims that, while the findings of various studies show that there is a strong relationship between job satisfaction and performance, it is not as strong as the influence of individual traits on performance.

Sariwulan, Agung, Sudrajat, and Atmadiredja (2019) conducted a study on the Effect of Job Expectations, Job Satisfaction, and Government Policies on Job Stress, Work Enthusiasm, and Continuing Commitment to Honorarium Teachers with the results of attention to honorary teachers, it shows that the variable affects their work stress conditions, and thus affect the honorary teachers.

According to the findings of these studies, the higher the employee's performance, the higher the employee's job satisfaction, and vice versa, if the employee's job satisfaction is low, the employee's performance suffers. As a result, the following hypotheses are put forward in this study:

H5: Job Satisfaction Improves the Performance of Private University Education Employees in Sleman Regency, Yogyakarta

\subsection{The Effect of OCB on Performance as Mediated by Job Satisfaction}

Employee performance is the result of a person's work, both in terms of quality and quantity, completed by the responsibilities delegated to him. Sutanto and Patty (2014) defined it as the level of absenteeism or attendance, the ability to meet 
targets, and the timeliness with which tasks were completed. According to Hariandja (2008), performance is defined as an employee's behavior about his or her role or job. Job satisfaction, according to Gu and Siu (2009), has an impact on employee performance. Todd (2003) asserts that OCB must affect organizational effectiveness by contributing to the social framework in the workplace. This is supported by the findings of $\mathrm{Gu}$ and Siu (2009) study, which found that job satisfaction influences employee performance. de Lara (2011) conducted research that provides a new understanding of how to improve employee performance, stating that increasing OCB will improve employee performance, particularly if job satisfaction increases, which will contribute significantly to improving employee performance. Employees with OCB, according to Asiedu, Sarfo, and Adjei (2014), will receive recognition and appreciation, as well as emotional satisfaction, resulting in improved performance. As a result, the following hypotheses are proposed in this study:

H6: Job satisfaction has the potential to moderate the effect of the variable Organizational Citizenship Behavior (OCB) on the Performance of Educational Employees at Private Universities in Sleman Regency, Yogyakarta.

\subsection{The Impact of Organizational Culture on Performance as Mediated by Job Satisfaction}

According to Kotter and Heskett (1997), a strong culture can have a significant impact on individuals and performance, even in a competitive environment, and the influence can be greater than other factors such as organizational structure, financial analysis tools, leadership, and others. An organizational culture that is easy to adapt to changing times (adaptive) can improve performance.

A strong organizational culture will help the organization provide certainty to all employees so that they can develop, grow, and develop the institution together. Employees must be instilled with an understanding of organizational culture from an early age. If employees enter an agency with varying characteristics and expectations, they will absorb the organizational culture through training, orientation, and adjustment, which will then develop into a group culture, and eventually be absorbed as a personal culture. If the process of internalizing organizational culture into personal culture is successful, employees will feel identical with the agency, united, and there will be no barriers to achieving optimal performance. This is a winwin situation for both the organization and the employees. According to Isnada (2016) research, organizational culture has a positive impact on employee performance.

According to Rongga (2001) research, organizational culture has the potential to improve employee job satisfaction. Furthermore, organizational culture is related to performance through employee job satisfaction, where organizational culture cannot be separated from organizational strategy, including the organization's vision and mission, and is one of the important factors in implementing strategies for 
improving performance within the organization. According to Pranita and Dewi (2018) research, organizational culture has a positive and significant effect on performance, with employee job satisfaction serving as a moderating variable. As a result, the following hypotheses are put forward in this study:

H7: Job satisfaction can mediate the influence of organizational culture variables on the performance of educational employees at private universities in Sleman Regency, Yogyakarta

The research paradigm's schema is as follows based on the description:

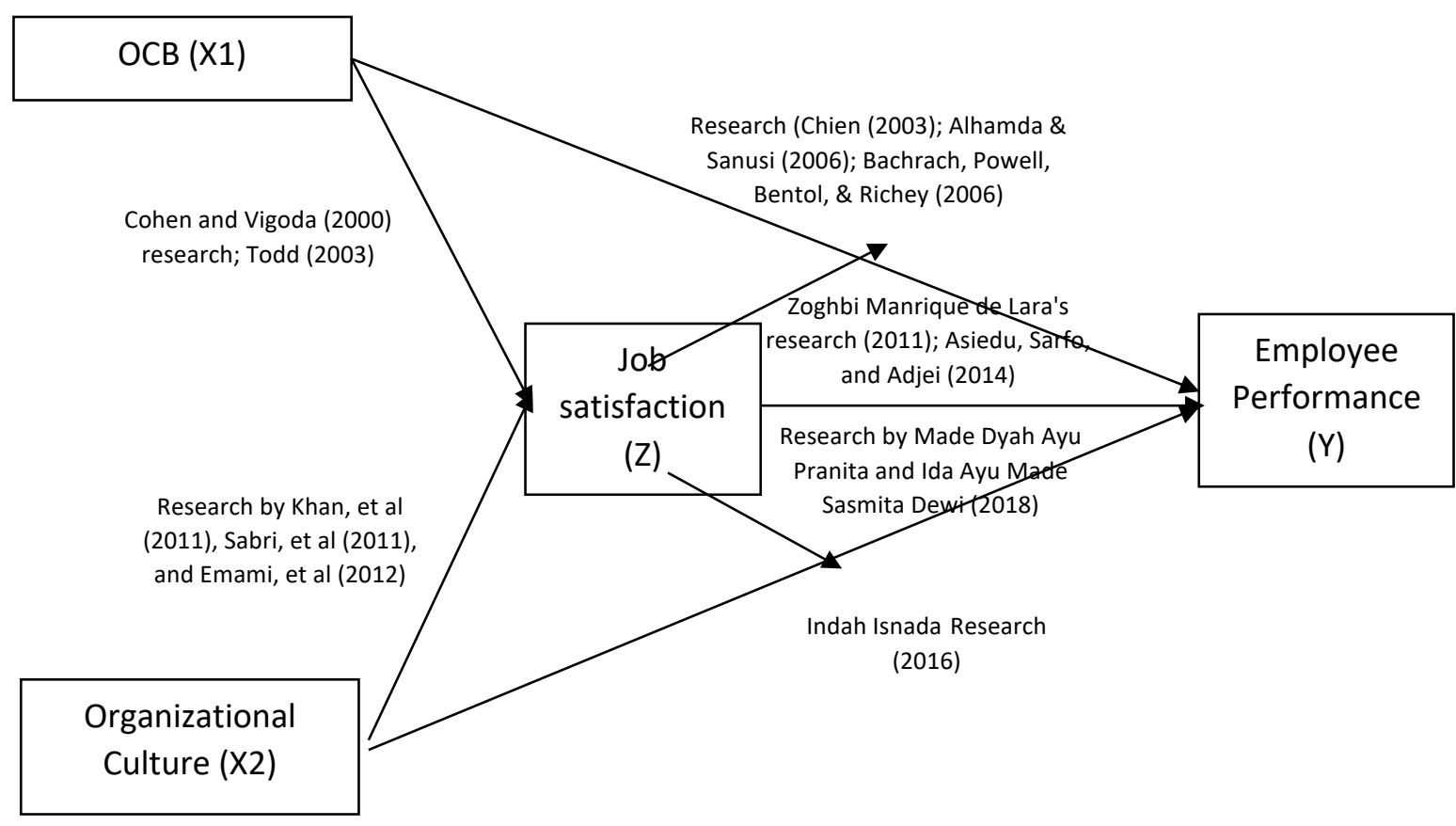

Figure 2. Research Paradigm Schematic

\section{METHODOLOGY}

In this study, the object of research, in general, includes an analysis based on Organizational Citizenship Behavior (OCB) and Organizational Culture called exogenous variables, which are variables that influence or cause changes or the emergence of endogenous variables, either positively or negatively, namely if there are variables exogenous, endogenous variables are also present with each unit inc (Sugiyono, 2010). The endogenous variable in this study is educational employee performance, and the intervening variable is job satisfaction. The setting for this study is a private university in Sleman Regency, Yogyakarta.

According to Sugiyono (2008), the population is a generalization area consisting of objects/subjects that have certain qualities and characteristics 
determined by researchers to be studied and then drawn conclusions from. In this study, the population consisted of 702 education employees from private universities in Sleman Regency. While the sample is a subset of the population. The sampling technique used is the proportional stratified random sampling method, which is a random sample selection method that can be done by first classifying a population into sub-populations. The lottery method was then used to select samples from each sub-population. According to Hasan (2005), the lottery method is a simple random sampling method in which the process is carried out using a lottery pattern.

The sample size in this study is calculated based on Hair et al (2006)'s opinion, which states that the number of representative samples is dependent on the number of measurement dimensions multiplied by 5 to 10 , and a sample that can meet these requirements is defined as:

$$
\text { Sample }=22 \text { (variable measurement indicator) } \times 6=132 \text { respondent }
$$

Only 130 of the 132 questionnaires distributed via Google Forms were returned. A total of 130 were able to meet the requirements to represent the research sample stated by Hair et al (2006) because Hair et al (2006) suggested that the minimum recommended sample size is 50 , and it would be better if it was more than 100 .

Meanwhile, the AMOS 24 program package was used to process the data. Structural Equation Modeling (SEM) analysis was used to test the hypothesis. SEM analysis is a cross-sectional, linear, and general statistical modeling technique.

\section{RESULT AND DISCUSSION}

\subsection{Criteria for determining the Goodness of Fit}

The primary goal of SEM is to determine how well the hypothesized model "fits" or fits the sample data. The goodness of fit structural analysis results are shown in the following data: 
Table 2. Goodness of Fit Index Test Results Structural Analysis Full Model

\begin{tabular}{lllll}
\hline \multirow{2}{*}{$\begin{array}{c}\text { The goodness } \\
\text { of Fit Index }\end{array}$} & $\begin{array}{c}\text { Research } \\
\text { Model }\end{array}$ & Cut-off Value & \multicolumn{2}{c}{ Model Evaluation } \\
\cline { 4 - 5 } & & Minimum & Gource & Criteria \\
\hline$X^{2}$ Chi-Square & 221,529 & $\geq 0,05$ & Ghozali (2018) & Not Fit \\
Probability & 0,000 & $\geq 0,08$ & Not Fit \\
RMSEA & 0,034 & $\leq 0,08$ & Ghozali (2018) & Fit \\
GFI & 0,869 & $\geq 0,90$ & Ghozali (2018) & Marginal Fit \\
AGFI & 0,829 & $\geq 0,90$ & Ghozali (2018) & Marginal Fit \\
CMIN/DF & 1,142 & $\leq 2,00$ & Ghozali (2018) & Fit \\
TLI & 0,983 & $\geq 0,95$ & Ghozali (2018) & Fit \\
CFI & 0,986 & $\geq 0,95$ & Ghozali (2018) & Fit
\end{tabular}

Source: Primary Data Processed (2021)

Only two criteria are declared unfit in the above Goodness of Fit test results, while the rest are classified as marginal fit to fit. As a result of this principle, the structural equation model testing results are accepted, and further analysis can begin.

\subsection{Flowchart to Structural Equation Conversion}

Figure 3 shows the results of data processing for structural analysis.

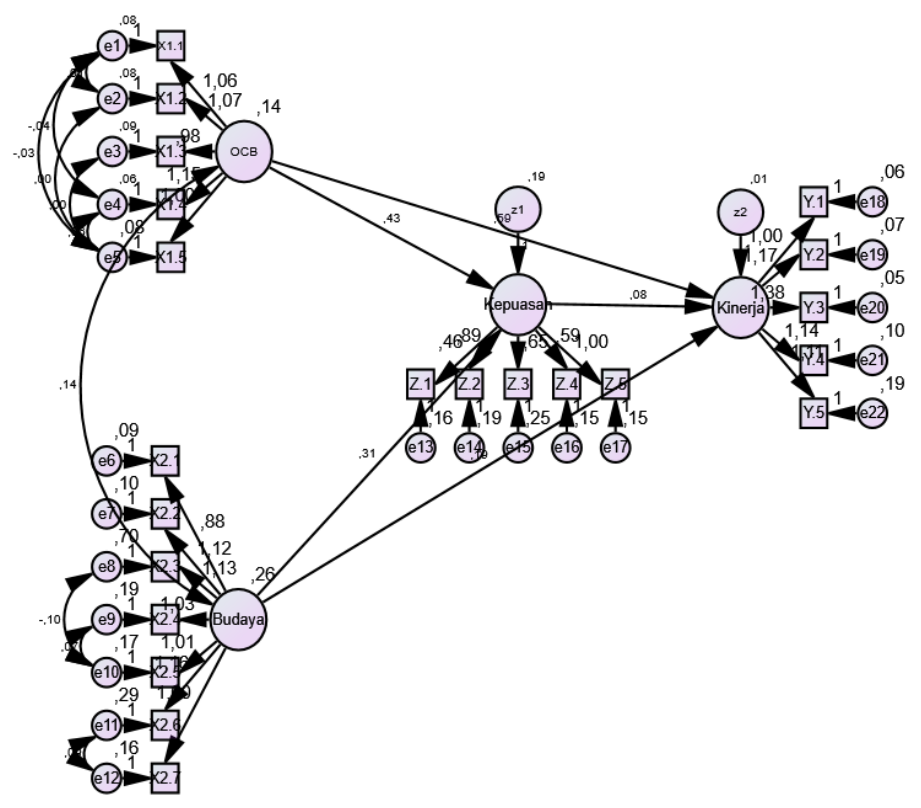

Figure 3. Structural Equation Model Drawing 


\subsection{Discussion}

The criteria for hypothesis testing in this study refer to Ghozali (2018), who argues that if the critical ratio (CR) value is $>1.96$ and the $p$-value is with a comparison of significance level $(\alpha=5 \%)$ or 00.05 , then the exogenous variable affects the endogenous variable, but if CR 1.96 and $p$-value> 0.05, then the exogenous variable does not affect the endogenous variable.

Table 3. Hypothesis Test Results

\begin{tabular}{|c|c|c|c|c|c|c|c|}
\hline & & & Estimate & S.E. & C.R. & $\mathbf{P}$ & Hypothesis \\
\hline OCB & $\rightarrow$ & Satisfaction & 0.432 & 0.210 & 2.059 & 0.039 & $\begin{array}{c}\text { Significant } \\
\text { Positive }\end{array}$ \\
\hline Culture & $\rightarrow$ & Satisfaction & 0.307 & 0.154 & 1.993 & 0.046 & $\begin{array}{c}\text { Significant } \\
\text { Positive }\end{array}$ \\
\hline Satisfaction & $\rightarrow$ & Performance & 0.081 & 0.041 & 1.972 & 0.049 & $\begin{array}{c}\text { Significant } \\
\text { Positive }\end{array}$ \\
\hline Culture & $\rightarrow$ & Performance & 0.194 & 0.057 & 3.418 & 0.000 & $\begin{array}{c}\text { Significant } \\
\text { Positive }\end{array}$ \\
\hline OCB & $\rightarrow$ & Performance & 0.591 & 0.094 & 6.286 & 0.000 & $\begin{array}{c}\text { Significant } \\
\text { Positive }\end{array}$ \\
\hline
\end{tabular}

Source: Primary Data Processed (2021)

\subsection{The Impact of Organizational Citizenship Behavior (OCB) on Job Satisfaction of Educational Employees at Sleman Regency Private Universities}

The estimated parameter value of the standardized regression weight coefficient obtained is 0.432 , and the CR is 2.059 , indicating a positive relationship between Organizational Citizenship Behavior and job satisfaction, with the better Organizational Citizenship Behavior resulting in higher job satisfaction. The probability value for testing these two variables is $0.039(p \leq 0.05)$. As a result, it is possible to determine whether there is a direct relationship between OCB and job satisfaction. The first hypothesis, that Organizational Citizenship Behavior (OCB) has a positive effect on Job Satisfaction of Private University Education Employees in Sleman Regency, Yogyakarta, is accepted.

Previous research by Iskandar, Hutagalung, and Adawiyah (2019) stated that job satisfaction and organizational commitment should be used concurrently to achieve better results. According to Pranata, Yasa, and Sitiari (2020), OCB has a positive and significant effect on employee performance. Lestari and Ghaby (2018) found that OCB has a significant positive effect on both job satisfaction and employee performance. Employee performance will improve as job satisfaction 
rises. Job satisfaction mediates the relationship between OCB and employee performance in part.

\subsection{The Impact of Organizational Culture on Job Satisfaction of Educational Employees at Sleman Regency Private Universities}

The estimated parameter value of the obtained standardized regression weight coefficient is 0.307 , and the CR is 1.993 , indicating a positive relationship between organizational culture and job satisfaction, implying that the better the organizational culture, the higher the job satisfaction. The probability value for testing these two variables is 0.046 ( $p \leq 0.05$ ). As a result, it is possible to determine whether there is a direct relationship between organizational culture and job satisfaction. Thus, Hypothesis 2 is accepted, Organizational Culture has a positive effect on Job Satisfaction of Private University Education Employees in Sleman Regency, Yogyakarta.

Previous research by Kawiana, Dewi, Martini, and Suardan (2018) demonstrates that organizational culture has a positive and significant effect on organizational commitment. According to Zukarnaen, Purwana, and Saptono (2020), the study's findings concluded that the school's work environment was good. Yamin (2017) which shows that partially there is an influence of organizational culture on job satisfaction, partially there is a significant influence of organizational commitment on job satisfaction, simultaneously there is a significant influence of organizational culture and organizational commitment on job satisfaction, partially there is no significant influence of organizational culture on employee performance, partially there is a significant effect of organizational commitment on employee performance, simultaneously there is a significant influence of organizational culture and organizational commitment on performance, there is a significant effect of employee job satisfaction on employee performance, the magnitude of the indirect influence of organizational culture on employee performance through employee job satisfaction, as well as the small indirect effect of organizational commitment on employee performance through employee job satisfaction at Bank Mega Branch Trans Studio Makassar. Pranita and Dewi (2018) discovered that organizational culture has a positive and significant effect on performance via employee job satisfaction as a mediating variable. Internal communication has a positive and significant effect on performance via employee job satisfaction as a moderating variable.

\subsection{The Impact of Organizational Citizenship Behavior (OCB) on Educational Employee Performance at Private Universities in Sleman Regency}

The estimated parameter value of the standardized regression weight coefficient obtained is 0.591 , and the $C R$ is 6,286 , indicating a positive relationship between OCB and performance, which means that the higher the OCB, the better 
the employee's performance. The probability value for testing these two variables is 0.039 ( $p \leq 0.05)$. As a result, it is possible to determine whether there is a direct relationship between OCB and performance. Thus, the third hypothesis, that Organizational Citizenship Behavior (OCB) has a positive effect on Job Satisfaction of Private University Education Employees in Sleman Regency, Yogyakarta, is accepted.

Previous research by Lestari (2018) shows that job satisfaction has a positive effect on employees via OCB. According to Nisa, Santoso, and Azhad (2018), organizational culture has an impact on employee performance and organizational citizenship. Employee performance is influenced by behavior.

\subsection{The Impact of Organizational Culture on Performance at Sleman Kabupaten's Private Universities}

The estimated parameter value of the standardized regression weight coefficient obtained is 0.194 , and the CR is 3.418 , demonstrating the relationship between organizational culture and positive performance, implying that the better the organizational culture, the better the work performance. The testing of these two variables yields a probability value of 0.000 ( $p \leq 0.05)$. Thus, it can be stated if there is a direct relationship between organizational culture and performance. The fourth hypothesis that Organizational Culture has a positive effect on the performance of Private University Education Employees in Sleman Regency, Yogyakarta, is accepted.

Previous research by Ratnasari, Rahmawati, Sutjahjo, and Yana (2018) found that leadership has a significant effect on the work behavior of lecturers in Batam City. The organizational culture has a significant impact on the work behavior of Batam City lecturers. Work motivation influences the work behavior of lecturers in Batam City Organizational Culture and Leadership Performance. Arafat and Haryono (2017). According to the findings of this study, organizational culture and work motivation have a positive effect on organizational commitment. Following an examination of the relationship between organizational culture, work motivation, organizational commitment, and performance, it is possible to conclude that organizational culture, work motivation, and organizational commitment all have a positive and significant impact on work performance.

\subsection{The Impact of Job Satisfaction on Performance at Sleman Regency Private Universities}

The estimated parameter value of the obtained standardized regression weight coefficient is 0.081 , and the $\mathrm{CR}$ is 1.972 , indicating a positive relationship between job satisfaction and performance, implying that the higher the job satisfaction, the higher the performance. The probability value for testing these two variables is 
$0.049(p \leq 0.05)$. As a result, if there is a direct relationship between job satisfaction and performance, it can be stated that hypothesis 5 is accepted, Job Satisfaction has a positive effect on the Performance of Private University Education Employees in Sleman Regency, Yogyakarta.

Previous research by Tuty Sariwulan, Iskandar Agung, Unggul Sudrajat, and Genardi Atmadiredja (2019) demonstrates that variables affect honorary teachers' work stress conditions, which in turn affect work morale and ongoing commitment.

The relationship shown below between the independent variable and the dependent variable through the mediating variable, namely by comparing the value of the standardized direct effect with the value of the standardized indirect effect, is one way to see the mediating relationship between the independent variable and the dependent variable through the mediating variable. It can be concluded that if the value of standardized direct effects is greater than the value of standardized indirect effects, the variable cannot mediate the influence of the independent variable on the dependent variable.

Table 4. Direct Effects (Group number 1 - Default model)

\begin{tabular}{|c|cccc|}
\hline & Culture & OCB & Satisfaction & Performance \\
\hline Satisfaction & 0.307 & 0.432 & 0.000 & 0.000 \\
Performance & 0.194 & 0.591 & 0.081 & 0.000 \\
\hline
\end{tabular}

Table 5. Inderect Effects (Group number 1 - Default model)

\begin{tabular}{|c|cccc|}
\hline & Culture & OCB & Satisfaction & Performance \\
\hline Satisfaction & 0.000 & 0.000 & 0.000 & 0.000 \\
Performance & 0.025 & 0.035 & 0.000 & 0.000 \\
\hline
\end{tabular}

\subsection{The Impact of Organizational Citizenship Behavior (OCB) on Performance at Private Universities in Sleman, Mediated by Job Satisfaction}

The effect of OCB on performance as mediated by job satisfaction compares the direct effect value to the indirect effect value, which is $0.591>0.035$. This indicates that job satisfaction is unable to mitigate the effect of OCB on educational employees' performance. This means that high job satisfaction cannot mediate the impact of organizational citizenship behavior (OCB) on performance. The link between OCB and performance is direct. Increased job satisfaction has no direct effect on OCB performance. Hypothesis 6 is rejected, job satisfaction does not 
mediate the influence of the Organizational Citizenship Behavior (OCB) variable on the Performance of Educational Employees at Private Universities in Sleman Regency, Yogyakarta.

Previous research by Siti Hidayah, Harnoto, and others somewhat contradicts this study (2018) Our findings highlight the potential role of job satisfaction and OCB in fostering perceptions of fairness in job performance. Endah Rahayu Lestari and Nur Kholifatul Fithriyah Ghaby (2018) concluded that the better the Organizational Citizenship Behavior (OCB) of the employees of PG Krebet Baru Malang, the more job satisfaction and employee performance would be, so the higher the job satisfaction felt by employees, the higher the job satisfaction felt by employees would be able to improve OCB performance.

\subsection{The Impact of Organizational Culture on Performance as Mediated by Job Satisfaction at Sleman Regency Private Universities}

The influence of organizational culture on performance as mediated by job satisfaction is compared using the direct effect value $0.194>0.025$. This suggests that job satisfaction is unable to mediate the impact of organizational culture on employee performance. This means that high job satisfaction cannot mediate the impact of organizational culture on performance. Organizational culture and performance have a direct relationship. Increased job satisfaction has no direct impact on organizational culture or performance.

This study contradicts previous studies by Mujiyanto, Sugiharto, Pramono, Sudana, and others (2020) that there is a significant influence of reward and organizational culture on lecturer performance. According to Buddhism, organizational culture variables are very important to develop and become a determining factor in improving lecturer performance. The leadership variable has no effect on lecturer performance. According to Utami and Sitohang (2019), the intensity of organizational culture at the Airlangga Health Center. Furthermore, the entire organizational culture is regarded as the most powerful organizational culture, including excellent service quality, discipline, cooperation, togetherness, and trust. According to Akbar (2019), organizational culture has a significant positive impact on job satisfaction. According to Koesmono (2005), organizational culture affects motivation and job satisfaction, and the performance of employees in the middlescale wood processing industry in East Java is acceptable.

\section{CONCLUSION}

The following conclusions can be drawn from the results of data analysis and hypothesis testing using structural equation modeling (SEM) found that Organizational Citizenship Behavior (OCB) and Organizational Culture has a positive effect on Job Satisfaction of Private University Education Employees in 
Sleman Regency, Yogyakarta. Organizational Citizenship Behavior (OCB) and Organizational Culture has a positive effect on the performance of Private University Education Employees in Sleman Regency, Yogyakarta. Moreover, Job Satisfaction has a positive effect on the Performance of Private University Education Employees in Sleman Regency, Yogyakarta. However, Job satisfaction is not able to mediate the influence of the variable Organizational Citizenship Behavior (OCB) and organizational culture variables on the Performance of Educational Employees at Private Universities in Sleman Regency, Yogyakarta.

Based on the findings, researchers can make the following recommendations and provide some input. First, agency leaders should maintain and improve the current level of OCB in the hope that employee performance can also be maintained and even improved. Agency leaders should also maintain and even improve the current level of organizational culture so that employee performance can be expected to be maintained and even improved. Even though it is not a moderating variable, agency leaders must increase employee job satisfaction to improve performance. However, employee job satisfaction can be increased by increasing OCB and strengthening organizational culture through informal events held outside of the office. In future research, more samples could be collected to improve data accuracy. The future research could improve for detection and assessment for any changes in the respondent's behavior from time to time. Hence, in the future research can add variables that will influence many aspects of this study.

\section{REFERENCE}

Mangkunegara, A.A.A.P. 2009. Manajemen Sumber Daya Manusia. Bandung: PT. Remaja Rosdakarya.

Adityasto, E. 2013. Minat Perilaku Dalam Pengadopsian Internet Banking: Theory Decomposed of TPB. Jurnal Ekonomi dan Bisnis.

Alhamda, S., \& Sanusi, R. 2006. Persepsi perilaku kepemimpinan, perilaku sebagai warga organisasi dan kinerja dosen Politeknik Kesehatan Padang Sumatera Barat. Tesis. IImu Kesehatan Masyarakat. Universitas Gadjah Mada. Yogyakarta.

Hendrawan, A., Laras, T., Sucahyowati, H., and Cahyandi, K. 2020. Peningkatan Kepemimpinan Transformasional Dengan Organizational Citizenship Behavior (OCB). The 11 th University Research Colloquium 2020 Universitas 'Aisyiyah Yogyakarta. 78-89. https://scholar.google.com/scholar?hl=id\&as_sdt=0\%2C5\&q=titi+laras\&btnG= 
Arikunto, S. 2002. Prosedur Suatu Penelitian: Pendekatan Praktek. Edisi Revisi Kelima. Jakarta: Penerbit Rineka Cipta.

As'ad. 2000. Seri Ilmu Sumber Daya Manusia Psikologi Industri, Edisi. Keempat. Yogyakarta: Liberti.

Asiedu, M., Sarfo, J. O., and Adjei, D. 2014. Organizational commitment and citizenship behavior: Tools to improve employee performance; An internal marketing approach. European Scientific Journal, 10(4), 288-305. Assessing the Construct Validity of Job Descriptive Index (JDI): A Review and Analysis.

Augusty, F. 2006. Metode Penelitian Manajemen: Pedoman Penelitian Untuk Penulisan Skripsi, Tesis dan Disertasi IImu Manajemen. Semarang: Badan Penerbit Universitas Diponegoro.

Augusty, F. 2006. Metode Penelitian Manajemen. Semarang: Badan. Penerbit Universitas Diponegoro.

Sastrohadiwiryo, B.S., 2003, Manajemen Tenaga Kerja Indonesia, edisi. 2, Jakarta, PT. Bumi Aksara.

Bachrach, D. G. et. al. 2000. Organizational citizenship behavior: A critical review of the theoretical and empirical literature and suggestions for future research. Journal of Management, 26, 513-563.

Bachrach, D. G., Powell, B. C., Bendoly, E., and Richey, R. G. 2006.

Organizational citizenship behavior and performance evaluations: Exploring the impact of task interdependence. Journal of Applied Psychology, 91(1), 193-201.

Wahyudi, B. 2002, Manajemen Sumber Daya Manusia. Jakarta: Sulita.

Belo, E. G. L. D. S., Riana, G., and Priartini, P. S. 2014. Pengaruh kepuasan kerja dan motivasi kerja terhadap komitmen organisasional dan kinerja karyawan di Kantor Palang Merah Timor Leste. E-Jurnal Ekonomi Dan Bisnis Universitas Udayana, 3(12), 718-737.

Buentelo, O., Jung, J., \& Sun, J. 2008. Exploring the Causal Relationship Between Organizational Citizenship Behaviour, Total Quality Management, and Performance. In 2008 SWDSI Proceedings. Oklahoma: Southwest Decision Sciences Institute.

Campbell D. T., \& Fiske, D. W. 1959. Convergent and discriminant validation by the multitrait-multimethod matrix. Psychological Bulletin, 56, 81-105. 
Chien, M. 2003. A study to improve organizational citizenship behaviors. In MODSIM 2003 International Congress on Modelling and Simulation. Integrative Modelling of Biophysical, Social, and Economic Systems for Resource Management Solutions. Townsville. Retrieved from https://www.mssanz.org.au/ MODSIM03/Volume_03/B14/03_Chien_Behaviours.pdf.

Cohen, A., and Vigoda, E. 2000. Do good citizens make good organizational citizens? An empirical examination of the relationship between general citizenship and organizational citizenship behavior in Israel. Administration \& Society, 32(5), 596-624.

Danang, S. 2012. Manajemen Sumber Daya Manusia. Jakarta: PT Buku. Seru.

David A. F and Tang, T.L. 2008. Job satisfaction and organizational citizenship behavior (OCB): Does team commitment make a difference in self-directed teams?. Management Decision, Vol. 46 Iss: 6, pp.933 - 947.

Dessler, Gary, 2011. Manajemen Sumber Daya Manusia. Penerbit Indeks, Jakarta.

Nisa, D.K, Santoso, B and Azhad, M.N. 2018. Pengaruh Budaya Organisasi dan Organizational Citizenship Behavior (OCB) terhadap Kinerja Pegawai Rumah Sakit Tk. III Baladhika Husada Jember. International Journal of Social Science and Business. Volume 2, Number 3, Tahun 2018, pp. 108-114.

Emami, R, Moradi, E., Idrus D., and Almutairi, D.O. 2012. Investigating the Relationship between Organizational Learning Culture, Job Satisfaction and Turnover Intention in it SMEs. International Journal of Innovative Ideas (IJII). Vol. 12(1), April 2012, pp. 8 - 23.

Lestari, E.R. and Ghaby, N.K.F. 2018. Pengaruh Organizational Citizenship Behavior (OCB) terhadap Kepuasan Kerja dan Kinerja Karyawan. Industria: Jurnal Teknologi dan Manajemen Agroindustri Volume 7 Nomor 2: 116-123 (2018), hal. 116-123.

Yamin, F. 2017. Pengaruh Budaya Organisasi dan Komitmen Organisasi terhadap Kinerja Karyawan dengan Kepuasan Kerja Karyawan sebagai Intervening (Studi Kasus Pada Bank Mega Branch Trans Studio di Makassar). Jurnal Penelitian. Yogyakarta: Fakultas Ekonomi Universitas Islam Indonesia.

Yulian, F. 2015, Pengaruh Budaya Organisasi Dan Kepuasan Kerja Terhadap Komitmen Organisasi Untuk Meningkatkan Kinerja Pegawai, Kinerja Vol 12 No.1. 2015, hal. 44-59.

Fornell, C., and Larcker, D. 1981. Evaluating Structural Equation Models with Unobservable Variable and Measurement Error. Journal of Marketing Research, Vol. 18, hal. $39-50$. 
Luthans, F. 2006. Perilaku Organisasi. Edisi Sepuluh, PT. Andi: Yogyakarta.

Ghozali, I. 2009. Aplikasi Analisis Multivariate Dengan Program SPSS. Edisi Keempat. Semarang: Penerbit Universitas Diponegoro.

Greenberg, J., and Baron, R. A. 2000 Behavior in Organizations: Managing the Human Side of Work, Seventh Edition. New Jersey: Prentice Hall International, Inc.

Gu, Z., and Siu, C.S.R. 2009. Drivers of job satisfaction as related to work performance in Macao casino hotels. International Journal of Contemporary Hospitality Management, 21(5), 561-578.

Hair, et al. 2010. Multivariate Data Analysis, Seventh Edition. Pearson Prentice Hall.

Handoko, T. H. 2001. Manajemen Personalia dan Sumber Daya Manusia. Yogyakarta: BPFE Yogyakarta.

Hariandja, M. T. E. 2008. Manajemen Sumber Daya Manusia: Pengadaan, Pengembangan, Pengkompensasian dan Peningkatan Produktivitas Pegawai. Jakarta: Grasindo.

Hariandja, M.T.E. 2005. Manajemen Sumber Daya Manusia. Jakarta: PT.Grasindo.

Hartline, M.D. and Ferrel, O. C. 1996. The Management of Customer-Contact Services Employees: An Empirical Investigation. Journal of Marketing.

Hasibuan, M.S.P. 2011. Manajemen Sumber Daya Manusia. Jakarta: PT Bumi Aksara.

Hui, C., Lam, S. S. K., and Law, K. K. S. 2000. Instrumental values of organizational citizenship behavior for promotion: A field quasi-experiment. Journal of Applied Psychology, 85(5), 822-828.

Umar, H. 2005. Metode Penelitian Untuk Skripsi dan Tesis Bisnis. Jakarta: PT. Raja Grafindo Persada.

Umar, H. 2004, Riset Sumber Daya Manusia Dalam Organisasi, Cetakan. Keempat, PT.GramediaPustaka Utama, Jakarta.

Isnada, I. 2016. Pengaruh Budaya Organisasi Terhadap Kinerja Pegawai Pada Sekretariat Daerah Kabupaten Mamuju Utara, e Jurnal Katalogis, Volume 4 Nomor 2, Februari 2016 hlm 62-75.

Jahangir, N., Akbar, M.M., Haq, M. 2004. Organizational citizenship behavior: Its nature and antecedents. BRAC University Journal, Vol. I. 
James, A.F.S, 2003, Manajemen, Edisi Bahasa Indonesia, Jilid II, Gramedia Grup, Jakarta.

Kaswan. 2012. Manajemen Sumber Daya Manusia untuk Keunggulan Bersaing Organisasi. Yogyakarta: Graha IImu.

Kaufman, J.D., Stamper, C.L., Tesluk, P.E. 2001. Do Supportive Organisations Make For Good Corporate Citizens?. Journal of Managerial Issues. Vol XIII Number 4.

Khan, V., Asma, M., Neelam, P. and Hasain, A. 2011. Impact of Organizational Culture on the Job Satisfaction of the Employees (Banking Sector of Pakistan). European Journal of Economics, Finance, and Administrative Sciences. (35), 2011, pp. 7-14.

Rongga, K.L. 2001. Human Resources Practices, Organizational Climate, and Employee Satisfaction, Academy of Management Review. July.

Kreitner, R and Kinicki, A. 2001. Organization Behavior. Fifth Edition. McGraw Hill. New York.

Kreitner, R. and Kinicki, A. 2005. PerilakuOrganisasi (Orgaizational. Behavior). Jakarta: Salemba Empat.

Kuncoro, M. 2003. Metode Riset Untuk Bisnis dan Ekonomi: Bagaimana Menulis Tesis dan Skripsi?. Jakarta: Penerbit Erlangga.

Liliweri, A. 2014. Sosiologi dan Komunikasi Organisasi. Jakarta: Bumi Aksara.

Locke, E. A. 1976. The Nature and Cause of Job Satisfaction in Handbook of Industrial and Organizational Psychology (Ed MD Dunette). Chicago: Rand Mc Narlly.

Pranita, M.D.A and Dewi, I.D.M.S. 2018. Pengaruh Budaya Organisasi dan Komunikasi Internal Terhadap Kinerja yang Dimediasi oleh Kepuasan Kerja Pegawai pada Dinas Kesehatan Kabupaten Tabanan. Jurnal Widya Manajemen Vol. 1, No. 1, November 2018, hal. 114-127.

Marihot, T.E.H. 2009. Manajemen Sumber Daya Manusia (Pengadaan, Pengembangan, Pengkompensasian, dan Peningkatan Produktivitas Pegawai). Cetakan Kelima. Jakarta: Grasindo.

Marwansyah. 2010. Manajemen Sumber Daya Manusia. Alfabeta: Bandung.

Mathis, R.L. and Jackson, J.H. 2006. Human Resource Management: Manajemen Sumber Daya Manusia. Terjemahan Dian Angelia. Jakarta: Salemba Empat

McClelland, D. 1961. The Achieving Society. New Jersey: Van Nostrand. 
Meyer, J. P. and Allen, N.J. 1991. A Three-Component Conceptualization of Organizational Commitment. Human Resource Management Review, 1(1), 61-89.

Meyer, J.P., Allen, N.J., and Smith, C.A. 1993. Commitment to Organizations and Occupations: Extension and Test of a Three-Component Conceptualization. Journal of Applied Psychology, pages 538-551.

Meyer, J.P. and Allen, N.J. 1990. The measurement and antecedents of affective, continuance, and normative commitment to the organization. Journal of occupational psychology, 63, 1-18.

Meyer, J.P. and Allen, N.J. 1997. Commitment in the workplace: Theory, Research, and Application. Thousand Oaks, CA: Sage Publication, Inc.

Mondy, R.W, 2010, Human Resource Management. Eleventh Edition.New. Jersey: Prentice-Hall.

Muchinsky, P.M. 2001. Psychology applied to work, an introduction to industrial and organizational psychology (7th $^{\text {th }}$ edition). California: Wardsworth Publishing Company.

Muray, R.A. 1999. Job Satisfaction of Professional and Paraprofessional Library Staff at the University of North Carolina at Chapel Hill. Theses.

Dewi, N.L.P.Y and Suwandana, I.G.M. 2016. Pengaruh Kepuasan Kerja Terhadap Organizational Citizenship Behavior (OCB) Dengan Komitmen Organisasional Sebagai Variabel Mediasi. E-Jurnal Manajemen Unud, Vol. 5, No.9, 2016:56435670.

Notoatmodjo. S. 2009. Pengembangan Sumber Daya Manusia. Cetakan Keempat. Edisi Revisi.

Nurbahar, R. 2015. Kepuasan Kerja Karyawan di PT Pos Indonesia (Persero) Cabang Kebumen. Naskah Publikasi. Fakultas Ekonomi. Universitas Negeri Yogyakarta.

Organ, D.W and Ryan, K. 1995. A Meta-Analysis Review of Attitudinal and Disposition Predictor of Organization Citizenship Behavior. Personnel Psychology, pp: 775-802.

Organ, D.W. 1988. Organizational Citizenship behavior: The good soldier syndrome. Lexington. MA: Lexington Books.

Organ, D.W. 1997. Organizational Citizenship Behavior: It's constructed cleanup time. Human Performance, 10(2), 85-97. 
Organ, D.W. 2015. Organizational Citizenship Behavior. In International Encyclopedia of the Social \& Behavioral Sciences (2nd ed., pp. 317-321). Elsevier Ltd.

Organ, D.W., and Lingl, A. 1995. Personality, satisfaction, and organizational citizenship behavior. The Journal of Social Psychology, 135(3), 339-350.

Organ, D.W., Podsakoff, P. M., and MacKenzie, S.B. 2006. Organizational citizenship behavior its nature, antecedents, and consequences. United States of America: Sage Publication, Inc.

Pasolong, H. 2008. Teori Administrasi Publik. Bandung: CV Alfabeta.

Podsakoff, P., MacKenzie, S.B., Paine, J.B., and Bachrah, D.G. 2000. Organizational citizenship behaviors: a critical review of the theoretical and empirical literature and suggestions for future research. Journal of Management, 26(3), 513-563.

Pratama, I. B. W., and Sriathi, A. A. A. 2015. Pengaruh stres kerja dan pemberdayaan terhadap kepuasan kerja karyawan di Prama Hotel. E-Jurnal Manajemen, 4(1), 3565-3591.

Purba, D.E and Seniati, A.L.L. 2004. Pengaruh Kepribadian dan Komitmen Organisasi terhadap Organizational Citizenship Behavior. Makara, Sosial Humaniora, 8(3), 105-111.

Qamar, N. 2012. Job Satisfaction and Organizational Commitment as Antecedents of Organizational Citizenship Behavior (OCB). Interdisciplinary Journal of Contemporary Research in Business, 4, 103- 122.

Rachmad, F.H, 2015, Universitas Tertua di Dunia Bukan Oxford, diakses dari https://news.okezone.com/read/2015/03/21/65/1122059/universitas-tertua-didunia-bukan-oxford.

Robbins, S. P. 1998. Organizational behavior: Concepts, Controversies, applications (8th ed). Upper Saddle River, NJ: Prentice-Hall.

Robbins, S, 2006, Perilaku Organisasi, Prentice-Hall, edisi kesepuluh.

Rodiathul, K.S, Mukzam, M.D. and Mayowan, Y. 2016. Pengaruh Budaya Organisasi Terhadap Kinerja Karyawan (Studi Pada Karyawan PT Karya Indah Buana Surabaya), Jurnal Administrasi Bisnis (JAB), Vol. 31 No. 1 Februari 2016, hal. 58-65.

Brown, S.P. 1996. A Meta-Analysis and Reviews of Organization Research and Involvement. Psychological Bulletin, 235 - 255. 
Sabri, P.S.U., Ilyas, M and Amjad, Z. 2011. Organizational Culture and Its Impact on The Job Satisfaction Of The University Teachers Of Lahore. International Journal of Business and Social Science. 2(24), 121-128.

Chaerani, S and Nimran,U. 2018. Pengaruh Organizational Citizenship Behavior (OCB) Terhadap Kepuasan Kerja (Studi pada Karyawan Divisi Human Capital Kantor Pusat PT. Bank Negara Indonesia (Persero),Tbk.), Jurnal Administrasi Bisnis (JAB), 60(2), 134-142.

Santosa and Ashari. 2005. Riset Pemasaran. Jakarta: PT. Gramedia Pustaka Utama.

Schermerhorn. J.R. and Osborn, J.H.R.N. 2009. Organization Behavior. $9^{\text {th }}$ edition. John Willey \& Sons, Inc.

Sekaran, U. 2006. Research Methods for Business Buku2. Edisi 4. Jakarta: Salemba Empat.

Siagian, S.P. 2008. Manajemen Sumber Daya Manusia (Edisi. Pertama). Jakarta: Binapura Aksara.

Steers, R.M., and Porter, L.W. 1983. Motivation and Work Behavior. Edisi Ke-3. New York: McGraw Hill Book Company.

Stoner, J.A.F. 2006. Manajemen, Terjemahan: Antarikso, dkk, Erlangga, Jakarta.

Sugiyono, 2008. Metode Penelitian Kunatitatif Kualitatif dan R \& D. Bandung. Alfabeta.

Sulistiyani, A.T and Rosidah. 2003. Manajemen Sumber Daya Manusia. Graha Ilmu: Yogyakarta.

Sumarsono, S. 2003. Ekonomi Manajemen Sumber Daya Manusia dan Ketenagakerjaan. Jogyakarta : Graha IImu.

Sutanto, E. M., and Patty, F. M. 2014. Persepsi akan gaji, motivasi kerja, dan kinerja karyawan PT Amita Bara Sejahtera. Journal of Business and Banking, 4(1), 1. https://doi.org/10.14414/jbb. v4i1.289.

Sutrisno, Edi. 2009. Manajemen Sumber Daya Manusia. Edisi pertama. Jakarta: Kencana Prenada Media Group.

Tett and Meyer. 1993. Job Satisfaction, Organizational Commitment, Turnover Intention, and Turnover: Path Analysis Based on Meta-Analysis Finding. Personnel Psychology. Summber 1993, pp 259-293.

Titisari, P. 2014. Peranan Organizational Citizenship Behavior: Meningkatkan Kinerja Karyawan. Jakarta: Mitra Wacana Media. 
Todd, S. Y. 2003. A Causal Model Depicting the Influence of Selected Task and Employee Variables on Organizational Citizenship Behavior. Florida State University.

Umam, K. 2012. Manajemen Organisasi. Bandung: Pustaka Setia.

Weiss, H. M., and Merlo, K. L. 2015. Job Satisfaction. In International Encyclopedia of the Social \& Behavioral Sciences (2nd ed., pp. 833-838). Elsevier Ltd.

Wibowo. 2010. Manajemen Kinerja. Jakarta: Rajawali Pers.

Putri, Y.D. and Utami, H.N. 2017. Pengaruh Organizational Citizenship Behavior (OCB) Terhadap Kinerja (Studi Pada Tenaga Perawat Ruang Rawat Inap Rumah Sakit Baptis Batu). Jurnal Administrasi Bisnis (JAB), 46(1), 27-34.

de Lara, Z.M.P. 2011. Whether Task Satisfaction Mediates the Effect of Fair Procedures on Citizenship. International Journal of Organizational Analysis, 19(3), 222-234. 